\title{
VENOUS REACTION TO PLASTIC INTRAVENOUS CANNULAE: INFLUENCE OF CANNULA COMPOSITION
}

\author{
M.V. JONES, B.SC. \\ DoUGLAS B. CRaIG, M.D., E.R.C.P.(C)
}

The use of Plastic intravenous cannulat during anaesthesia and the postoperative period has become commonplace. With this widespread use, however, has come evidence suggesting an increased complication rate, when compared to that for metal needles. ${ }^{1}$ Many factors have been shown to influence venous or surrounding tissue reaction to intravenous cannulae. These include site of infusion, ${ }^{2}$ duration of infusion ${ }^{3}$ and the types of fluids or drugs infused. ${ }^{1,4}$ Thomas et al. found an increased incidence of tisste reaction with the use of plastic as opposed to metal needles. ${ }^{1}$ They also found some differences between plastic cannulae of different composition, but were unable to make definite conclusions on this point. It was the objective of the present study to attempt to establish a relationship between tissue reaction and cannula composition, while at the same time taking into account other factors of known or assumed importance.

\section{METHODS}

Four cannulae were studied as listed in Table I. Fewer patients are in the cannula \#4 group as it was introduced into the study at a later stage than were cannulae \#1 to \#3.

TABLE I

Details of Intravenous Cannulae Studied

\begin{tabular}{|c|c|c|c|c|c|}
\hline & Cannula & Composition & $\begin{array}{l}\text { Gauge } \\
\text { length }\end{array}$ & $\begin{array}{c}\text { No. of } \\
\text { patients }\end{array}$ & $\%$ \\
\hline 1 & Argyle Medicut & Polypropylene & $\begin{array}{l}18 \mathrm{G} \\
2 \text { inch }\end{array}$ & 89 & 29.5 \\
\hline 2 & Jelco I.V. Catheter & Polyviny]chloride & $\begin{array}{l}18 \mathrm{G} \\
2 \text { inch }\end{array}$ & 80 & 26.5 \\
\hline 3 & Jelco Cathlon IV & $\begin{array}{l}\text { TFE-Teflon } \\
\text { Polvtetrafluorethylene }\end{array}$ & $\begin{array}{l}18 \mathrm{G} \\
2 \text { inch }\end{array}$ & 87 & 28.8 \\
\hline 4 & Longdwell & $\begin{array}{l}\text { FEP-Teflon } \\
\text { Fluoroethylene propylene }\end{array}$ & $\begin{array}{l}18 \mathrm{G} \\
2.5 \text { inch } \\
\quad \text { Total }\end{array}$ & $\frac{46}{302}$ & 15.2 \\
\hline
\end{tabular}

Patients undergoing elective operations and requiring establishment of an intravenous route formed the study population. Three hundred and sixty-five patients entered the study but 63 were later excluded because of incomplete follow-up data. There were 159 males ( 52.7 per cent) and 143 females ( 47.3 per cent) with a mean age of 54.5 years (S.D. 20.7, range 15-93). The type of operation was noted but since we found no significant direct correlation between the operation and reaction to the cannulae, this information will not be presented.

491

Canad. Anaesth. Soc. J., vol. 19, no. 5, September 1972 
Two anaesthesia technicians, working in a pre-operative patient waiting area, inserted all cannulae, following a fixed technique. The cannulae were used on a rotation basis, so that every fourth patient received the same type.

Following application of an elastic tourniquet, a suitable vein was selected on the dorsum of the hand (197, or 65.2 per cent), at the wrist (21, or 7 per cent) or on the forearm ( 84 , or 27.8 per cent). The overlying skin was prepared with a swab soaked in 70 per cent alcohol, and 1 per cent lidocaine (less than $0.5 \mathrm{cc}$ ) was infiltrated. Following insertion of the cannula a small amount of Neosporin topical ointment (polymixin B, bacitracin, neomycin) was applied to the puncture site. An occlusive adhesive wound dressing was then applied. The trauma of insertion of each cannula was estimated on a scale of 1 (least) to 4 (most) by the technician.

Fluids and drugs were administered as required clinically. This is summarized in Table II with subjects placed in seven groups, based on the agents administered through the cannulae.

TABLE II

Patients Grouped According to Agents

Administered Through I.V. Cannulae

\begin{tabular}{clcr}
\hline \hline Group & \multicolumn{1}{c}{ Agents } & $\begin{array}{c}\text { No. of } \\
\text { patients }\end{array}$ & $\%$ \\
\hline 1 & I.V. fuids only* & 15 & 5 \\
2 & I.V. fluids + pentothal & 39 & 13 \\
3 & Above + succinylcholine & 96 & 32 \\
4 & Above + curare or gallamine & 64 & 21 \\
5 & and atropine + prostigmine & 33 & 11 \\
6 & Addition of narcotics & 12 & 4 \\
7 & Addition of blood or dextran & 43 & 14 \\
& Addition of KCl, diazepam & & \\
& or antibiotics & 302 & 100 \\
\hline
\end{tabular}

*5\% dextrose in water; $\mathbf{0 . 9 \% ~} \mathrm{NaCl}$; Ringers lactate, or combinations.

The duration of the infusions ranged from 1 to 99 hours (mean 18.3 hours; S.D. 19.0). Patients were visited by one of the authors every 24 hours following insertion of the cannula until there had either been no reaction observed for 24 hours following its removal or until an observed reaction had cleared.

Venous and non-venous complications were assessed according to a simplified version of the criteria used by Thomas et al. ${ }^{1}$ Each patient has been classified according to the most severe reaction observed. In some cases this was not seen until 48 hours following removal of the cannula.

Non-venous reactions were assessed as:

Type 1. No reaction. A clean puncture wound.

Type 2. Discolouration, or swelling only in area of puncture site. No redness, pain or tenderness.

Type 3. Swelling, with pain and tenderness, in area of puncture site.

Venous reactions noted were:

Type 1. None.

Type 2. Thrombosis only. Induration along the vein, without evidence of phlebitis. 
Type 3. Phlebitis - tenderness and red streak along the vein. Usually accompanied by surrounding oedema.

Type 4. Thrombophlebitis - Type 3 plus induration along the vein. (Only one patient developed this reaction.)

At removal of the cannula in 51 subjects ( 17 per cent) cultures were taken of its terminal part. The mean duration of infusion for this group was 34.0 hours (S.D. 20.7, range 2-76) while for the 251 subjects not cultured it was 15.1 hours (S.D. 17.0, range 1-99). The technique of removal and culture was as follows. The dressing was removed, the skin carefully wiped with three swabs soaked in 70 per cent alcohol, and then allowed to dry. A sterile saline-soaked swab was applied to the puncture site and then innoculated on blood agar, which was incubated for 3 days at $37^{\circ} \mathrm{C}$. The cannula was removed, its tip (about $1 \mathrm{inch}$ ) was cut off, using sterile scissors and placed in Robertson's cooked meat medium and incubated for 3 days at $37^{\circ} \mathrm{C}$.

Statistical analyses were performed using the facilities of the Computer Department for Health Sciences, University of Manitoba. All comparisons except those for age and duration of infusion were by Chi-square analyses. Age and infusion duration correlations with venous and non-venous reactions were examined using a one-way analysis of variance. A "p" value of 0.05 or less was considered significant.

\section{RESULTS}

The correlations of the observed non-venous reactions with other factors are summarized in Table III. Table IV lists the correlations between venous reaction and other factors.

TABLE III

ReI-ATIONSHIP OF NoN-VenOUS Reactions to Other Variables as Examined hy ChI-Souare Tests. 302 Patients

\begin{tabular}{lcc}
\multicolumn{1}{c}{ Factor } & P Value & $\begin{array}{c}\text { Statistica! } \\
\text { significance }\end{array}$ \\
\hline Cannula type & $>0.5$ & $\mathrm{NS}$ \\
Patients age & $>0.3$ & $\mathrm{NS}$ \\
Patients' sex & $<0.01$ & $\mathrm{~S}$ \\
& (Female reaction more than male) \\
Cannula placement site & $>0.3$ & $\mathrm{NS}$ \\
Trauma of insertion & $>0.1$ & $\mathrm{NS}$ \\
Duration of infusion & $<0.01$ & $\mathrm{~S}$ \\
Drugs infused & $<0.05$ & $\mathrm{~S}$ \\
Venous reaction & $<0.01$ & $\mathrm{~S}$ \\
\hline
\end{tabular}

The relationship of cannula type to venous reaction is illustrated in Figure 1. The Chi-square contingency table for this comparison indicated that the differences between cannula types was due to a decreased incidence of "no reaction" and an increased incidence of thrombosis for the Type 2 cannula. This difference is also apparent in Figure 1. This Figure also suggests that the Type 3 cannula 
TABLE IV

Relationghip of Venous Reactions to Other Variagles as Examined by Chi-Square Tests. 302 Patients

\begin{tabular}{lcc}
\hline \hline \multicolumn{1}{c}{ Factor } & P Value & $\begin{array}{c}\text { Statistical } \\
\text { significance }\end{array}$ \\
\hline Cannula types 1, 2,3,4 & $<0.05$ & $\mathrm{~S}$ \\
Cannula types 1, 3,4 & $>0.4$ & $\mathrm{NS}$ \\
Patients' age & $>0.2$ & $\mathrm{NS}$ \\
Patients' sex & $>0.5$ & $\mathrm{NS}$ \\
Cannula placement site & $<0.05$ & $\mathrm{~S}$ \\
$\quad$ Forearm highest, hand lowest rate of reactions) & $\mathrm{NS}$ \\
Trauma of insertion & $>0.5$ & $\mathrm{~S}$ \\
Duration of infusion & $<0.01$ & $\mathrm{~S}$ \\
Drugs infused, groups 1-7 & $<0.01$ & $\mathrm{NS}$ \\
Drugs infused, groups 1-4 & $>0.3$ & \\
\hline
\end{tabular}

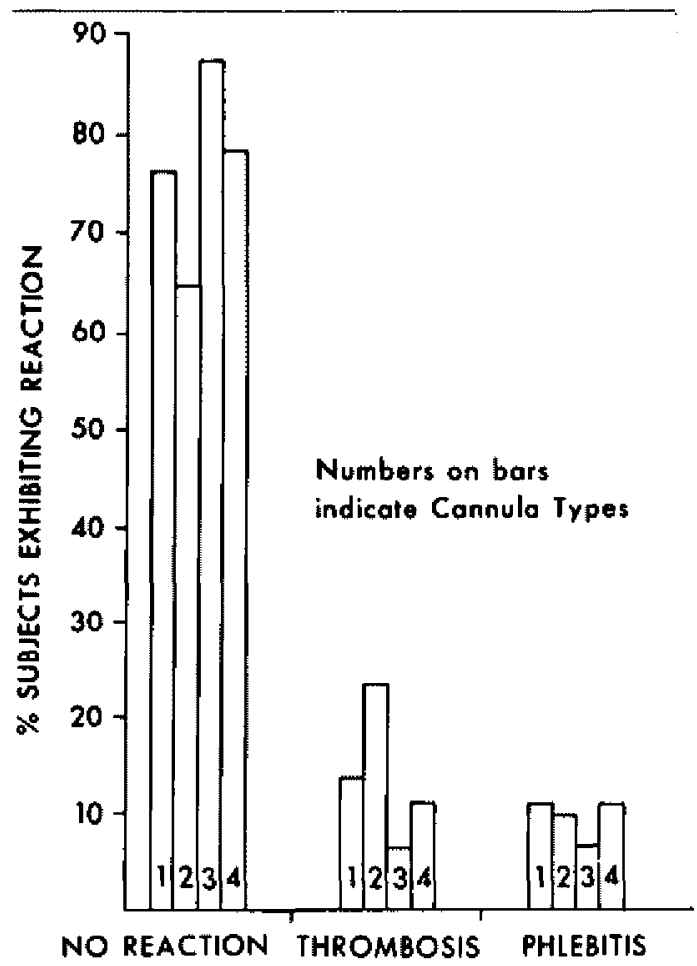

Fugure 1. Percentage of subjects in each cannula group exhibiting venous reactions. 301 subjects. One subject with thrombophlebitis (Type 2 cannula) not included. 
was superior, although this is not supported by the statistical analysis, which indicated no significant difference between cannulas 1,3 , and 4 ,

It is apparent from Table IV that exclusion of drug groups 5, 6, and 7 removes the correlation between drugs infused and venous reaction. Accordingly, the results were re-analyzed, but excluding those patients (88) who had received these agents. As seen in Table V, exclusion of these patients does not alter the correlations noted in Table IV.

None of the 51 cannula tips which were cultured grew any organisms. One skin swab grew coagulase negative staphylococci.

TABLE $V$

Relationship of Venous Reactions to Other Variables Excluding Patients from Table II, Groups 5, 6, 7, 214 Patients

\begin{tabular}{lcc}
\hline \hline \multicolumn{1}{c}{ Factor } & PValue & $\begin{array}{c}\text { Statistical } \\
\text { significance }\end{array}$ \\
\hline Cannula type 1, $2,3,4$ & $<0.05$ & S \\
Cannula type 1, 3,4 & $>0.2$ & NS \\
Duration of infusion & $<0.01$ & $\mathrm{~S}$ \\
Cannula placement site & $<0.05$ & $\mathrm{~S}$ \\
Trauma of insertion & $>0.5$ & $\mathrm{NS}$ \\
\hline
\end{tabular}

\section{Discussion}

Several factors have been shown in this study to influence the incidence of venous reactions to the intravenous cannulae. In agreement with previous studies these are site (2) and duration (3) of infusion, and the types of drugs infused $(1,4)$. These factors have been extensively discussed elsewhere. The basic purpose of this investigation was to deternine whether cannula composition influences venous reaction. The answer to this question is a qualified yes. There was a significantly increased incidence of thrombosis associated with the type 2 polyvinyl chloride unit. As shown in Table V, this difference persists even after the elimination from the series of those patients who received intravenous drugs which are known irritants. The type 3 TFE - Teflon cannula showed a decreased (but not significant) incidence of both thrombosis and phlebitis, as seen in Figure 1. Considering statistical significance therefore, the conclusion must be that cannula number 2 should be ranked worst, while numbers 1,3 , and 4 are equal, but better than type 2. Whether the magnitude of the differences observed have significant clinical implications, however, is not as clear. If one were to consider only the incidence of phlebitis, then the differences between cannulae disappear, again as is apparent in Figure 1.

The low overall incidence of phlebitis, and the failure to grow organisms from cannula tips is worthy of comment. This may reflect the techniques of insertion and dressing which were followed, including the use of an antibiotic ointment and an occlusive dressing. ${ }^{5}$ It may also be related to the assignment of the-maintenance care of intravenous carnulae to a special team of nurses in our hospital. 
They tend to change the site of infusion at the earliest symptom or sign of venous irritation, thus likely avoiding progression to more severe problems. ${ }^{6}$

The lack of correlation of the estimates of the trauma of insertion of the cannulae with venous or non-venous reactions may mean that there is in fact no such relationship. More likely, however, it may indicate an inability to make an accurate estimate of the trauma involved.

The possibility must also be considered that differences between the cannulae other than their composition might have influenced the results. The most obvious factor is the difference in canmula design, most particularly between Type 1 and Types 2, 3, and 4 . Elimination of this factor would require the special manufacture of cannulae of identical design but different composition.

\section{SUMMARY}

Venous reactions following insertion of plastic intravenous cannulae were studied in 302 patients. Four types of cannulae of different chemical composition were studied. Venous reactions increased with the duration of infusion and with the addition of irritant drugs to the infusion fluids. The highest incidence of venous reaction occurred with the use of a polyvinyl chloride cannula. There was less reaction associated with the other three cannulae, which were composed of polypropylene, TFE-Teflon, and FEP-Teflon. There was no significant difference between these three cannulae. It is concluded that clinically important differences in complications could not be attributed to the differences in cannula composition.

\section{RÉSUMÉ}

On a étudié chez 302 malades les réactions veineuses survenues à la suite d'applications de canules intraveineuses en plastique. Quatre genres de canules de différente composition chimique ont été étudiées. Les réactions veineuses ont augmenté avec la durée de la perfusion et avec l'addition de produits irritants au liquide injecté.

La plus haute fréquence de réactions veineuses s'est produite en utilisant les canules de chlorure de polyvinyl. Il y eut moins de réactions avec les trois autres genres de canules, lesquelles étaient composées de polypropylène, de TFETeflon et de FEP-Teflon. Entre ces trois dernières, il n'y eut aucune différence notable.

En conclusion, des différences cliniquement importantes dans les complications ne pouvaient pas être attribuées aux différences dans la composition des canules.

\section{ACKNOWLEDGMENT}

The assistance of Mrs. C. Taback, Miss J. Dunford, and Mr. W. Forsyth in this study is gratefully acknowledged. 


\section{REFERENCES}

1. Thomas, E.T., Evers, W., \& Racz, G.B. Post-infusion phlebitis. Anesth. \& Aralg, 49: 150$159(1970)$.

2. Fonkalsaud, E.W., Penergon, B.M., Munphy, J, \& Beckefeman, J.H. Reduction of infusion thrombophlebitis with buffered glucose solutions. Surgery 63: 280-284 (1968).

3. Medical Research Council Report: thrombophlebitis following intravenous infusions: a trial of plastic and rubber-giving sets. Lancet 1: 595-597 (1957).

4. HästaAcka, J., TAMMisto, T., El.Fving, G., \& Titinen, P. Infusion thrombophlebitis. Acta Anaesth. Scand. 10: 9-30 (1965).

5. Mohan, J.M., ATWOOD, R.P., \& RowE, M.I. A clinical and bacteriologic study of infections associated with venous cutdowns. New Eng. J. Med. 272: 554-560 (1965).

6. FuCHs, P.C. Indwelling intravenous polyethylene catheters. Factors influencing the risk of microbial colonization and sepsis. J.A.M.A. 216: 1447-1450 (1971). 